\title{
Fluid and Electrolyte Observations in Tropical Surgical Practice
}

\author{
LAURENCE F. TINCKLER,* M.D., CH.M., F.R.C.S., D.T.M.\&H.
}

Brit. med. F., 1966, 1, 1263-1267

In countries of temperate climate, such as the United Kingdom, the fluid and electrolyte requirements for a patient recovering from surgery are well known. During the past decade much work has been done on the metabolic response to trauma, and a great deal of information has been documented (Moore and Ball, 1952). Those studies, however, have been carried out mainly in North America and Europe, and as such are strictly applicable only to patients under like conditions. The different circumstances of surgical patients in the tropics, both racial and climatic, make it probable that there are differences in their requirements to an extent that appears, as yet, to be insufficiently known.

Wilkinson (1960) states: " Since more major surgery is done in those hot countries where the bulk of the world population is found, the effects of hot and humid climates on the distribution of water and minerals in the body become increasingly important to the surgeon. At present there is little information on which to base estimates of water and sodium requirements in hot and humid environments during the first week after a major operation or severe injury, and judgement is even more difficult in unacclimatized patients. There is a wide scope for study of these aspects of surgery in tropical countries."

Since the last war many data have been obtained concerning fluid and electrolyte studies in hot climates, but these are largely confined to Servicemen and employees of industrial concerns such as oil companies, and are directed to the avoidance and treatment of heat illnesses and the problems of acclimatization (Leithead et al., 1958 ; Leithead and Pallister, 1960).

Populations of the so-called emergent countries in hot climates now have available to them the benefits of modern surgical treatment. This is due to improved economic circumstances and to foreign aid in providing for more hospitals staffed by local-born medical graduates who have received specialist training abroad. There is a growing need for all possible information on surgical practice in hot climates, and it is salutary to reflect that very few textbooks are devoted to surgery in the tropics (Bowesman, 1960). It is fallacious, moreover, to assume that the information gained from postgraduate training in the United Kingdom, for example, can be applied direct to surgical problems in tropical countries. There is much that is similar, but the extent to which differences exist will not be known until adequate inquiry is made.

\section{Present Investigation}

This paper is an account of an investigation into some aspects of fluid and electrolyte requirements of surgical patients in the tropics. The aim was to determine how much fluid was lost via the lungs and from the skin surface of patients recumbent in surgical-ward beds under tropical climatic conditions. In hot climates, owing to the requirements of thermoregulation, the surgical patient has a route of fluid loss of potentially significant magnitude. The question is how much fluid and electrolyte loss occurs via these routes, and therefore how much must be allowed for in replacement calculations for patients under standard ward conditions in the tropics. Is it negligible? Is it enormous?

- Professor of Surgery, University of Singapore.
This investigation was designed to answer the question. Apart from possible subtle racial differences in the metabolic response to trauma, only fluid and electrolyte loss via the skin and lungs is likely to differ significantly in patients in tropical areas compared with these in temperate climates. As sweating is involved in the mechanism of regulation of body temperature, it would be anticipated that surgical patients in tropical areas require greater amounts of fluid than those in temperate climates. Furthermore, as sweat is an electrolytic solution, the same anticipation might be applied to sodium and potassium as the most important bulk ions of the body.

The investigation was of limited extent and in the nature of a pilot study, and was carried out during summer months in Quatar and Bahrain, both sheikdoms in the Persian Gulf. It was conducted in three parts-a survey of total body water in the local population and an assessment of "insensible" fluid loss and of sweat electrolytes in hospital patients.

Friend (1932) pointed out that the Persian Gulf is an area where the summer climate is particularly severe, being situated in the region where the Tropic of Cancer traverses the land masses of North Africa, Arabia, and India. In these territories there are large expanses of desert with high air temperatures. The patients were under investigation, awaiting operation, or convalescing from surgery. The wards were not air-conditioned but opened on to shady verandas with good through ventilation and ceiling fans. Even so, the wet-and-dry-bulb temperatures for the ward taken daily at 10 a.m. and 6 p.m. showed that for about half of each 24 hours the ward atmosphere was extremely hot and humid, with average dry-bulb temperatures of $90-95^{\circ} \mathrm{F}$. $\left(32.2-35^{\circ}\right.$ C.) and wet-bulb temperatures of $80-85^{\circ}$ F. (26.7$29.5^{\circ}$ C.).

\section{Thermoregulation}

Thermoregulation-that is to say, the physiological processes by which heat produced by the body's metabolism is either dissipated or conserved to maintain body temperature within narrow confines of normality-is carried out by adjustments of cutaneous blood-flow and activation of the sweating mechanism. At ambient temperatures below $85^{\circ} \mathrm{F}$. $\left(29.5^{\circ} \mathrm{C}\right.$. $)$ variations in the amount of blood flowing through the skin vessels is adequate to convey heat from the "core" tissues of the body to the "shell," whence it is lost to the environment by radiation and convection. As the ambient heat load increases above $85^{\circ} \mathrm{F} .\left(29.5^{\circ} \mathrm{C}\right.$. $)$ the heat-energy gradient between the body (normal temperature $98-99^{\circ}$ F. ; 36.7-37.2 ${ }^{\circ}$ C.) and the environment decreases, and progressively less heat can be dissipated in this way. It is in these circumstances that sweating plays an essential part in thermoregulation, as it becomes the sole means by which heat can be lost from the body. Sweat secreted on to the skin surface evaporates into the atmosphere with utilization of energy (latent heat of vaporization of water) obtained from body heat. Fluid loss in hot climates is governed by requirements of thermoregulation not operating significantly in temperate climates.

Latent heat of vaporization of the water lost from the body via the lungs in saturating expired air and via skin transudation also dissipates heat. This is a mode of heat loss that is outside thermal regulatory control, and takes place "insensibly" at air 
temperatures below $30^{\circ} \mathrm{C} .\left(86^{\circ} \mathrm{F}\right.$.). At greater ambient temperatures the sweating mechanism comes into play as a means of dissipating heat from the body, and the amount of sweating is directly proportional to the heat stress (Leithead and Lind, 1964).

\section{Total Body Water}

Patients admitted to hospital for elective surgery for conditions not themselves associated with any metabolic upset had a total body-water assessment. All the subjects were male; 34 observations were made, and each was carried out on the day the patient was admitted to hospital.

The nude body weight of each patient was recorded and $1 \mathrm{ml}$. of tritiated water of $1 \mathrm{mc}$. radioactivity was injected intravenously. Two hours later, by which time equilibration of the tritium had taken place throughout all body-water compartments, a specimen of venous blood, about $10 \mathrm{ml}$., was withdrawn into a container containing sodium oxalate as anticoagulant. The plasma water of each specimen was obtained by centrifuging down the cells and pipetting off the plasma, from which the proteins were precipitated by the addition of $100 \%$ trichloroacetic acid $(0.1 \mathrm{ml}$. of $100 \%$ trichloroacetic acid to each $1 \mathrm{ml}$. of plasma) and separated from the plasma water by centrifugation. The plasma water was dispatched by air to the U.K. for coincidence liquid scintillation counting. When the radioactivity of the plasma water was known the total body water could be calculated as follows:

$$
\begin{gathered}
\text { Total body water } \\
\text { (in litres) }
\end{gathered}=\frac{100}{\begin{array}{c}
\text { Percentage of given tritium dose } \\
\text { per litre of plasma water }
\end{array}}
$$

The results of 34 observations are given in Table I, and the relationship between total body-water values and the body weight in Fig. 1.

\begin{tabular}{|c|c|c|c|c|c|c|c|}
\hline $\begin{array}{l}\text { Sub- } \\
\text { ject } \\
\text { No. }\end{array}$ & $\begin{array}{c}\text { Body } \\
\text { Water } \\
\text { (1.) }\end{array}$ & $\begin{array}{c}\text { Weight } \\
\text { (kg.) }\end{array}$ & $\begin{array}{l}\text { Body Water } \\
\text { as Percentage } \\
\text { of Body } \\
\text { Weight }\end{array}$ & $\begin{array}{l}\text { Sub- } \\
\text { ject } \\
\text { No. }\end{array}$ & $\begin{array}{c}\text { Body } \\
\text { Water } \\
\text { (1.) }\end{array}$ & $\begin{array}{l}\text { Weight } \\
\text { (kg.) }\end{array}$ & $\begin{array}{l}\text { Body Watcr } \\
\text { as Percentage } \\
\text { of Body } \\
\text { Weight }\end{array}$ \\
\hline $\begin{array}{r}1 \\
2 \\
3 \\
4 \\
5 \\
6 \\
7 \\
8 \\
9 \\
10 \\
11 \\
12 \\
13 \\
14 \\
15 \\
16 \\
17\end{array}$ & $\begin{array}{l}32 \cdot 3 \\
32 \cdot 1 \\
34 \cdot 7 \\
28 \cdot 9 \\
34.7 \\
31 \cdot 6 \\
29 \cdot 7 \\
30 \cdot 1 \\
26 \cdot 6 \\
27 \cdot 9 \\
28 \cdot 7 \\
31 \cdot 6 \\
30 \cdot 7 \\
30 \cdot 0 \\
28 \cdot 4 \\
21 \cdot 0 \\
31.0\end{array}$ & $\begin{array}{l}48 \cdot 23 \\
53.92 \\
54.5 \\
49.85 \\
52.35 \\
48.48 \\
46 \cdot 16 \\
44.24 \\
42.47 \\
43.54 \\
43.02 \\
44.35 \\
53.25 \\
47.55 \\
37.12 \\
49.0 \\
48.0\end{array}$ & $\begin{array}{l}67 \cdot 0 \\
59 \cdot 6 \\
63.5 \\
57 \cdot 9 \\
66 \cdot 2 \\
65.3 \\
64 \cdot 2 \\
68 \cdot 2 \\
62 \cdot 8 \\
64 \cdot 0 \\
66 \cdot 7 \\
71 \cdot 2 \\
57 \cdot 7 \\
63 \cdot 1 \\
76.5 \\
43.0 \\
65.0\end{array}$ & $\begin{array}{l}18 \\
19 \\
20 \\
21 \\
22 \\
23 \\
24 \\
25 \\
26 \\
27 \\
28 \\
29 \\
30 \\
31 \\
32 \\
33 \\
34\end{array}$ & $\begin{array}{l}40.0 \\
33 \cdot 0 \\
38 \cdot 0 \\
42.5 \\
34 \cdot 0 \\
37 \cdot 0 \\
21 \cdot 0 \\
43.5 \\
35 \cdot 0 \\
36 \cdot 0 \\
41 \cdot 0 \\
33 \cdot 0 \\
28.5 \\
41.5 \\
27.5 \\
37 \cdot 0 \\
36.0\end{array}$ & $\begin{array}{l}57 \cdot 0 \\
55 \cdot 0 \\
50 \cdot 0 \\
56 \cdot 0 \\
70 \cdot 0 \\
56 \cdot 0 \\
40 \cdot 0 \\
91 \cdot 0 \\
56 \cdot 0 \\
53 \cdot 0 \\
79 \cdot 0 \\
52 \cdot 0 \\
40 \cdot 0 \\
56 \cdot 0 \\
50 \cdot 0 \\
50 \cdot 0 \\
47 \cdot 0\end{array}$ & $\begin{array}{l}70 \cdot 0 \\
60.0 \\
76 \cdot 0 \\
76 \cdot 0 \\
48.5 \\
66 \cdot 0 \\
52.5 \\
48 \cdot 0 \\
62.5 \\
68 \cdot 0 \\
52 \cdot 0 \\
63.5 \\
71.0 \\
74.0 \\
55.0 \\
74.0 \\
76.5\end{array}$ \\
\hline
\end{tabular}

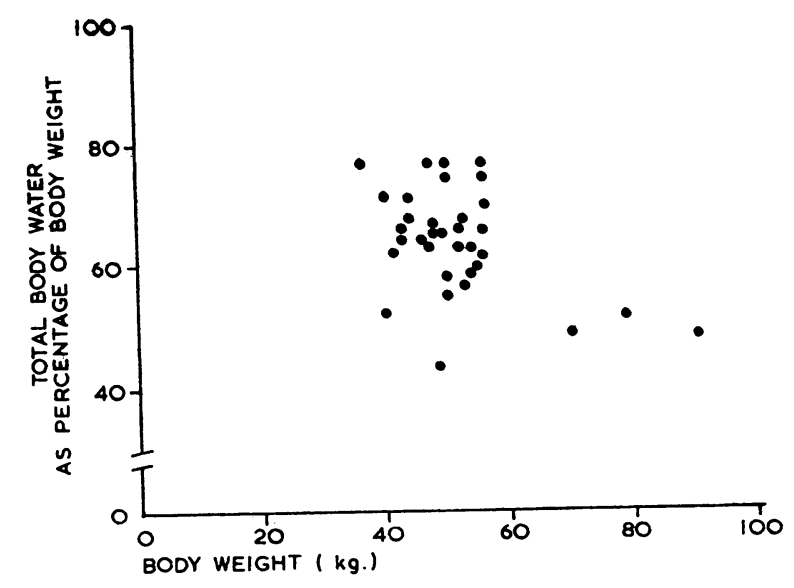

Fug. 1.- Total body water related to body weight in 34 subjects.

\section{Fluid Loss}

Fluid-balance studies were carried out in 54 patients. As this investigation was done concurrently with a heavy surgical service commitment, its design was made simple in the interests of accuracy, as staff were not readily available to supervise the patients closely over long periods. The nude weight of each patient was recorded at the beginning and end of the balance period on a Spido scale (type BSW Van Vochs concern), which weighed to an accuracy of $10 \mathrm{~g}$. The results are shown in Tables II and III. Throughout the investigation the ward air temperature was recorded on wet-and-dry-bulb thermometers at 10 a.m. and 6 p.m. and the humidity calculated from the tables.

\section{Group I : 15 Patients (24-hour Study)}

Each patient was given a known quantity of water and sodium chloride. The 24-hour volume of urine was noted and daily nude-body weighing carried out. To ensure accurate input and output figures $5 \%$ glucose solution and isotonic saline was given to the patients by Ryle's tube intragastric drip but nothing else for the period of study. The complete collection of urine was ensured by attaching a length of Paul's tubing to the patient's penis, and through this he micturated direct into a bedside bottle. Nude-body weights were recorded at the same time each morning. By knowing the volume of fluid intake, the urinary output, and the body weight, loss of fluid from the skin surface and in the expired air was calculated for each 24-hour period (Table II).

\begin{tabular}{|c|c|c|c|c|c|c|c|}
\hline $\begin{array}{l}\text { Sub- } \\
\text { ject }\end{array}$ & Date & $\begin{array}{c}\text { Body } \\
\text { Weight } \\
\text { (kg.) }\end{array}$ & $\begin{array}{l}\text { Fluid } \\
\text { Loss } \\
\text { (ml.) }\end{array}$ & $\begin{array}{c}\text { Sub- } \\
\text { ject }\end{array}$ & Date & $\begin{array}{c}\text { Body } \\
\text { Weight } \\
\text { (kg.) }\end{array}$ & $\begin{array}{l}\text { Fluid } \\
\text { Loss } \\
\text { (ml.) }\end{array}$ \\
\hline $\begin{array}{l}1 \\
2 \\
3 \\
4 \\
5 \\
6 \\
7 \\
8\end{array}$ & 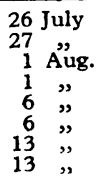 & $\begin{array}{l}60 \cdot 63 \\
58 \cdot 9 \\
50 \cdot 78 \\
47 \cdot 89 \\
63 \cdot 03 \\
51 \cdot 74 \\
48 \cdot 75 \\
44 \cdot 67\end{array}$ & $\begin{array}{l}2,300 \\
2,160 \\
1,950 \\
1,410 \\
1,560 \\
1,850 \\
2,400 \\
1,630\end{array}$ & $\begin{array}{r}9 \\
10 \\
11 \\
12 \\
13 \\
14 \\
15\end{array}$ & $\begin{array}{l}13 \text { Aug. } \\
15 \text { "”, } \\
10 \text { Sept. } \\
10 \text { "” } \\
24 \text { "” } \\
24 \text { "” }\end{array}$ & $\begin{array}{l}55 \cdot 17 \\
44 \cdot 81 \\
59 \cdot 55 \\
46.99 \\
44.38 \\
50.63 \\
51 \cdot 14\end{array}$ & $\begin{array}{r}2,900 \\
2,540 \\
1,390 \\
1,110 \\
980 \\
1,140 \\
1,120\end{array}$ \\
\hline
\end{tabular}

\section{Group II : 39 Patients (Four-hour Study)}

These patients were weighed nude at the beginning and end of a four-hour period, during which they took nothing by mouth and passed neither urine nor faeces. Differences in weight were solely due to extrarenal loss of fluid (Table III).

Patients chosen for this study were those able to cooperate and who had agreed to participate ; they were either awaiting operation or well convalescent from surgery, or undergoing clinical investigation. At at rate, they were those for whom deprivation of fluid intake for a limited period under observation would prove no detriment or discomfort.

For the period of study the balance was simplified to nil intake and nil output. Any alteration in the subject's weight was therefore attributable to fluid loss via the lungs and skin. As these observations were made shortly after the patients had taken their meals and had been given an opportunity to urinate and defaecate, the conditions of the study caused no discomfort for its limited duration. In order to ensure that the requirements of the test were strictly observed the patients were constantly supervised and confined to bed (Fig. 2).

\section{Sweat Composition}

In four patients sweat was collected from the body surface at several sites by the following technique. The skin was swabbed several times with distilled water to remove any traces 


\begin{tabular}{|c|c|c|c|c|c|c|c|}
\hline & & & $T_{A}$ & & & & \\
\hline \multirow{2}{*}{$\begin{array}{l}\text { Sub- } \\
\text { ject }\end{array}$} & \multirow{2}{*}{ Date } & \multirow{2}{*}{ Age } & \multicolumn{2}{|c|}{$\begin{array}{c}\text { Body } \\
\text { Weight } \\
\text { (kg.) }\end{array}$} & \multirow{2}{*}{$\begin{array}{l}\text { Fluid } \\
\text { Loss } \\
\text { (ml.) }\end{array}$} & \multicolumn{2}{|c|}{ Air Temperature } \\
\hline & & & Start & Finish & & $\begin{array}{l}\text { Dry- } \\
\text { bulb }\end{array}$ & $\begin{array}{l}\text { Wet- } \\
\text { bulb }\end{array}$ \\
\hline
\end{tabular}

\begin{tabular}{|c|c|c|c|c|c|c|c|}
\hline \multicolumn{8}{|c|}{ Four-hourly Sweat Loss in Afternoon (2-6 p.m.) (15 cases) } \\
\hline $\begin{array}{r}1 \\
2 \\
3 \\
4 \\
5 \\
6 \\
7 \\
8 \\
9 \\
10 \\
11 \\
12 \\
13 \\
14 \\
15\end{array}$ & 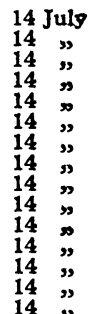 & $\begin{array}{l}60 \\
55 \\
31 \\
60 \\
25 \\
35 \\
16 \\
30 \\
28 \\
60 \\
30 \\
30 \\
70 \\
60 \\
45\end{array}$ & $\begin{array}{l}48.61 \\
54.38 \\
54.98 \\
50.37 \\
52.92 \\
48.99 \\
46.73 \\
44.82 \\
44.09 \\
43.55 \\
42.93 \\
44.7 \\
47.4 \\
52.91 \\
41.28\end{array}$ & $\begin{array}{l}48 \cdot 23 \\
53 \cdot 92 \\
54.5 \\
49 \cdot 85 \\
52.35 \\
48 \cdot 48 \\
46 \cdot 16 \\
44.24 \\
43 \cdot 54 \\
43.02 \\
42.47 \\
44.35 \\
47.00 \\
52.47 \\
40.87\end{array}$ & $\begin{array}{l}380 \\
460 \\
480 \\
520 \\
570 \\
510 \\
570 \\
580 \\
550 \\
530 \\
460 \\
350 \\
400 \\
440 \\
410\end{array}$ & $\begin{array}{l}94 \\
94 \\
94 \\
94 \\
94 \\
94 \\
94 \\
94 \\
94 \\
94 \\
94 \\
94 \\
94 \\
94 \\
94\end{array}$ & $\begin{array}{l}84 \\
84 \\
84 \\
84 \\
84 \\
84 \\
84 \\
84 \\
84 \\
84 \\
84 \\
84 \\
84 \\
84\end{array}$ \\
\hline & & & & verage & 480 & & \\
\hline
\end{tabular}

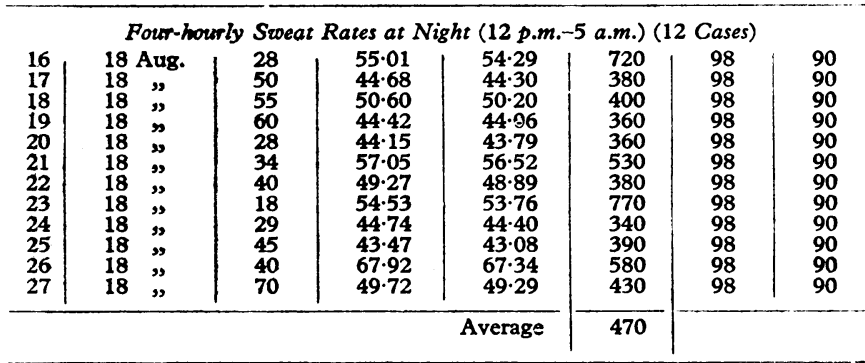

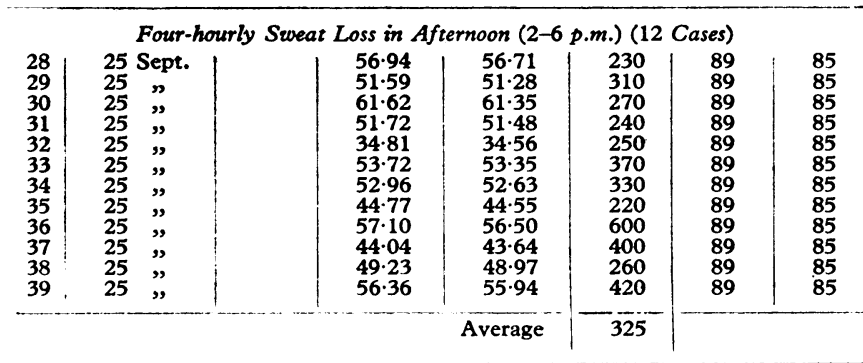

of sweat and dried by blotting with gauze. Two pieces of filter-paper (Whatman) were then placed on the skin and covered with a sheet of polyethylene, which had been well washed in distilled water to remove salt. The polyethylene sheet was then held in place by adhesive tape at the edges, thus sealing up the filter-paper and preventing evaporation of sweat from the area. After several hours in contact with the skin the filter-papers were placed in a plastic container with a screw top to await electrolyte analysis of the absorbed sweat. The quantity of sweat was obtained by weighing the sweatsoaked filter-paper and deducting the known dry weight of the paper. The electrolyte content of the sweat was obtained by leaching out with a known quantity of distilled water and estimating sodium and potassium by flame photometry (Table IV).

\begin{tabular}{|c|c|c|c|c|c|}
\hline TABLE I & IV.-Sweat & Electr & ytes & & \\
\hline & Subject: & A & B & C & D \\
\hline 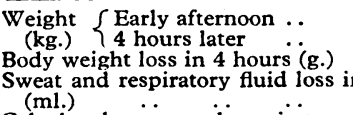 & $\begin{array}{cc}\cdots & \cdots \\
\because & \cdots \\
\text { in } & 4 \\
\cdots & \cdots\end{array}$ & $\begin{array}{r}51 \cdot 12 \\
50 \cdot 41 \\
710 \\
710\end{array}$ & $\begin{array}{r}58.21 \\
57.58 \\
630\end{array}$ & $\begin{array}{r}58.68 \\
57.91 \\
770\end{array}$ & $\begin{array}{r}43 \cdot 05 \\
42 \cdot 40 \\
650\end{array}$ \\
\hline $\begin{array}{l}\text { Calculated sweat and respiratory } \\
\text { in } 24 \text { hours (ml.) }\end{array}$ & fluid loss & 4,260 & 3,780 & 4,620 & 3,900 \\
\hline Sweat analysis $\left\{\begin{array}{l}\mathrm{Na}(\mathrm{mEq} / \mathrm{l} .) \\
\mathrm{K}\end{array}\right.$ & & $\begin{array}{l}10 \\
67\end{array}$ & ${ }_{7 \cdot 8}^{11}$ & $\begin{array}{l}8 \cdot 3 \\
5 \cdot 8\end{array}$ & $\begin{array}{l}8 \\
7 \cdot 2\end{array}$ \\
\hline
\end{tabular}

\section{Discussion}

It cannot be overemphasized that the patient recovering from gastro-intestinal surgery in the immediate post-operative period is entirely dependent on his medical attendants for the correct prescription -and provision of fluid, among other things, to meet his requirements. Accurate provision depends on precise knowledge of requirements, which in turn is dependent on information on fluid losses. The normal wide limits of tolerance of water intake are greatly narrowed in the post-operative period, and therefore provision of fluid must be precise enough to avoid dehydration on the one hand and water intoxication on the other.

Normally the individual takes fluid in obedience to the prompting of thirst sensation, and at other times according to habit and as a means of indulging himself with flavoursome beverages. As a rule overall fluid intake tends to be in excess of requirements, and a healthy renal mechanism exists to eliminate this excess of "free" water. The post-operative patient is unable to tolerate extremes of fluid administration owing to the metabolic response to injury resulting in salt-andwater retention under the influence of an increased output of corticosteroids and the antidiuretic hormone.

\section{Fluid Loss}

Of the various routes of fluid loss from the post-operative patient-urine, gastric aspiration, bile-duct drainage, ileostomy efflux-those from skin surface and via the lungs are the ones not susceptible to easy direct measurement and therefore accurate replacement. That being so, it is customary to make an approximation for this "insensible" loss and allow $1,000 \mathrm{ml}$. for it in the 24-hourly replacement calculation (Le Quesne, 1957). This has the merit of being satisfactory in practice in temperate regions, but is it so for hot climates ?

Fluid is lost from the skin surface by two processes-simple transudation, a passive process, and sweating consequent upon the activity of sweat glands in the skin.

Fluid loss from the body via the expired air and by transudation through the skin is termed "insensible loss"; it is governed by physical factors-air movement and humidity; it occurs continuously, and is outside physiological control.

Fluid loss from the skin as sweat, on the other hand, is not a continuous process ; it occurs in particular circumstances

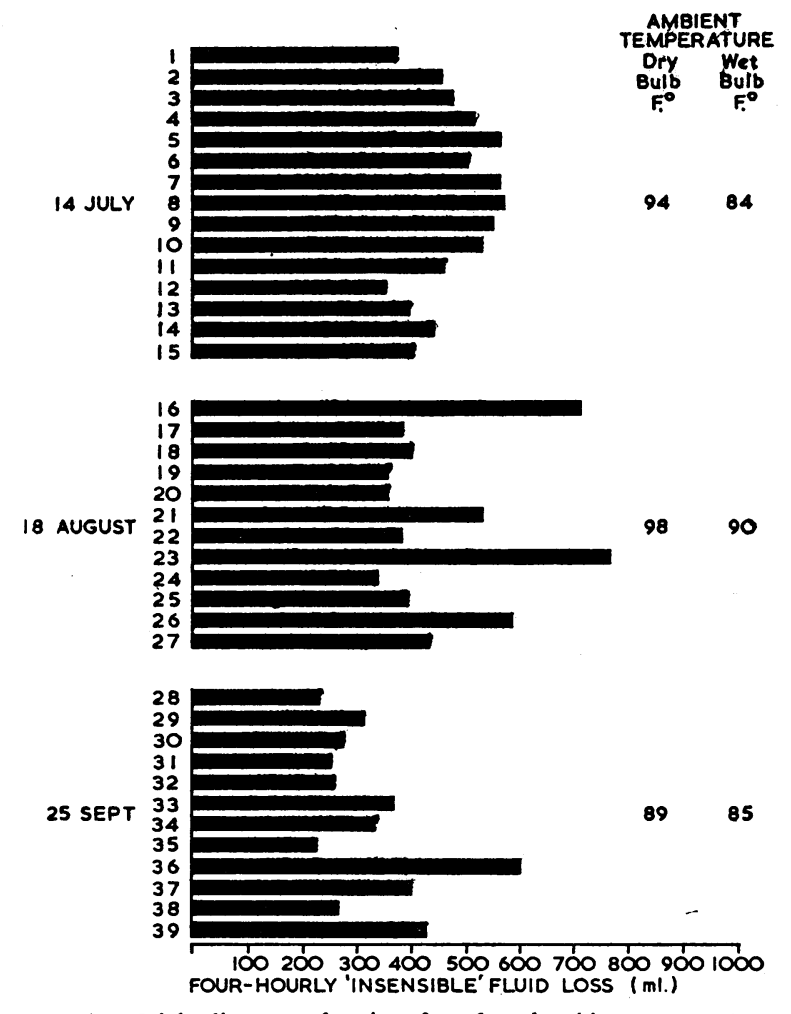

FIG. 2.-Stick diagram showing four-hourly skin and respiratory fluid loss in 39 surgical patients in Persian Gulf summer. 
under physiological control, which is part of the mechanism for thermoregulation. It is the product of active secretion by skin glands, which can be regarded as analogous to the nephrons of the kidney.

Expired air is saturated with water vapour and is invariably so whatever the water content of the inspired air, as water is added to the respirate from the body tissues during its transit through the air passages. It follows that the amount of water lost from the body during respiration will be governed by the humidity of the atmosphere breathed-the drier the air the more fluid required to saturate it ; the more humid the air the less fluid required to saturate it and the less the fluid loss.

Again, the amount of fluid lost by transudation through the skin and evaporation from its surface is not associated with thermoregulation. The amount and rate of this transudation is dependent on the atmospheric content of water vapourthe humidity in so far as it determines the concentration gradient: the lower the humidity the greater the loss by transudation and evaporation.

\section{Climatic Conditions}

Apart from possible ethnic considerations, the essential difference in the physiology of surgical patients in temperate and hot countries is that imposed by vastly different climatic conditions. During the Persian Gulf summer the daytime drybulb temperatures were mostly over $90^{\circ} \mathrm{F} .\left(32.2^{\circ} \mathrm{C}\right.$.). There was little fall in temperature during the night owing to the maritime situation-a geographical feature which always serves to approximate day and night temperatures. Humidity in the area during the same period was around $80 \%$.

The difference between the fluid and electrolyte turnover of a patient in a temperate climate and one in a hot climate is that the latter has an extra route of fluid and electrolyte loss, owing to the need to sweat as an essential part of the body mechanism for thermoregulation.

In temperate climates fluid is lost insensibly from the skin surface by diffusion of tissue fluid through the cuticle, a process that is termed perspiration. No electrolytes are lost with the fluid by this means, which occurs as a physical process. Together with the water vapour present in expired air, the daily loss is taken to average no more than $1,000 \mathrm{ml}$.

In hot climates the necessity for the body to maintain a constant internal temperature of about $98.4^{\circ} \mathrm{F}$. $\left(36.9^{\circ} \mathrm{C}\right.$.) or a " core" temperature of $99.5^{\circ} \mathrm{F} .\left(37.5^{\circ} \mathrm{C}\right.$.) in the face of a high ambient temperature brings into operation the sweating mechanism whereby loss of heat from the body is achieved. Failure of sweating due to exhaustion of sweat glands or dehydration promptly results in a rise of body temperature, which may reach hyperpyrexia levels $\left(106^{\circ} \mathrm{F} .+; 41.1^{\circ} \mathrm{C} .+\right.$ ), leading to irreversible cerebral damage. The necessity of supplying the surgical patient with sufficient fluid to permit adequate sweating is thus apparent under tropical conditions.

Sweating is an obligatory process and has first call on body water, a threat to the mechanism of haemostasis (Weiner and Hellman, 1960). Leithead (1960) has shown that sweating is decreased in the face of body dehydration, so that failure to keep post-operative patients sufficiently hydrated jeopardizes their heat-loss mechanism, with the attendant danger of heat exhaustion or hyperpyrexia. With prevailing ward temperatures of $90^{\circ} \mathrm{F} .+\left(32.2^{\circ} \mathrm{C} .+\right)$ in the Persian Gulf, the importance of sweating to the well-being of these patients, and the need to have sweat losses replenished, can be appreciated.

\section{Subjects}

The subjects of these observations were reasonably healthy persons recumbent throughout the test, metabolizing basally or near basally and therefore producing heat minimally. Recorded insensible fluid-loss values as a consequence can be taken also to be minimal for the circumstances of the test. Other surgical patients-as, for instance, those in the immediate post-operative recovery period and patients suffering from infective processes or such hypermetabolic conditions as thyrotoxicosis-would, owing to an increased production of body heat, be expected to lose greater amounts of fluid as sweat.

Results of the fluid-loss study reveal that the conventional allowance of $1,000 \mathrm{ml}$. for insensible loss for patients in the United Kingdom is insufficient for patients in open wards in hot climates. For general prescription in areas of climatic conditions, such as those of the Persian Gulf summer, the provision of a minimum of $2,000 \mathrm{ml}$. of fluid every 24 hours for adult patients is a more realistic figure.

The average total body water in 34 subjects, all male, was $63 \%$ of the body weight. Edelman et al. (1952), in an assessment of total body water in 34 normal male subjects by use of deuterium oxide (heavy water), found a mean of $61 \%$, with a range of $53-70 \%$. In the present investigation $5(15 \%)$ of the subjects were found to have a total body water less than the lowest figure in the range quoted by Edelman et al. (1952), and in them a state of dehydration may be presumed.

As all the subjects were selected to exclude those with an organic cause for dehydration-for example, pyloric stenosisreduced body water noted in some of them was probably due to so-called "voluntary dehydration"-that is to say, a failure of the subject to drink enough to meet his normal requirements.

The suggested clinical importance of this observation is its possible association with incipient oligaemia, with the attendant liability of circulatory failure being precipitated by any development which reduces vasomotor tone-for example, the administration of general anaesthesia.

The electrolyte content of sweat among the small number of subjects studied was found to be low, in the region of $10 \mathrm{mEq} / 1$. for sodium, and would not account for a significant bulk ion loss from the body. It must be taken into account, however, that the subjects were of local stock, fully adapted and acclimatized. A reduction of sodium concentration in sweat is a feature of the acclimatization process, and is due to the action of aldosterone on sweat-gland epithelium (Collins, 1963). The sodium content of sweat of subjects in temperate climates may be as high as $80 \mathrm{mEq} / 1$., according to Kuno (1956). In unacclimatized patients, therefore, electrolyte loss from the skin surface due to sweating may be significant, and would have to be taken into consideration in prescribing replacement therapy in post-operative management.

It may be concluded that, for the adult surgical patient who is acclimatized to hot conditions and who has had no prior fluid and electrolyte depletion, the post-operative requirements to cover loss via the skin surface and lungs can be met by providing 2-4 litres of fluid. The fluid can be given intravenously as isotonic $5 \%$ dextrose, there being no necessity to give saline, as the sodium loss in sweat is insignificant. This amount is double or treble the requirements of adult patients in temperate climates.

For the unacclimatized patient it would be prudent to give $250 \mathrm{ml}$. of each litre of fluid as normal $(0.9 \%)$ saline, containing $37.5 \mathrm{mEq}$ of sodium, to cover sodium loss in sweat.

\section{Summary}

An account is given of an investigation of total body water, cutaneous and respiratory fluid loss, and sweat electrolyte composition in surgical patients during the hot summer climate of the Persian Gulf.

Results reveal a degree of voluntary dehydration in some patients, and a daily cutaneous and respiratory fluid loss of 
2-4 litres and low concentration of bulk ions in the sweat of fully acclimatized subjects.

The relevance of these findings to the post-operative management of surgical patients in hot climates is discussed.

It is a pleasure for me to acknowledge the help I have received in carrying out this investigation from Dr. W. Kulke, of the Liverpool Radium Institute, for providing facilities for radioisotope counting, and from Mr. D. Jenkins, senior laboratory technician of the Bahrain Medical Service, for the sweat analysis.

\section{REFERENCES}

Bowesman, C. (1960). Surgery and Clinical Pathology in the Tropics. Livingstone, Edinburgh and London.
Collins, K. J. (1963). Fed. Proc., 22, 716.

Eaeiman, I. S., Haley, H. B., Schloreb, P. R., Sheldon, D. B., FriisHansen, B. J., Stoll, G., and Moore, F. D. (1952). Surg. Gynec. Obstet., 95,1 .

Friend, N. B. (1932). Med. 7. Aust., 1, 232.

Kuno, Y. (1956). Human Perspiration. Thomas, Springfield, Illinois.

Le Quesne, L. P. (1957). Fluid Balance in Surgical Practice. LloydLuke, London.

Leithead, C. S. (1960). Trans. roy. Soc. trop. Med. Hyg., 54, 297. Guthrie, J., De La Place, S., and Maegraith, B. (1958). Lancet, 2, 109.

and Lind, A. R. (1964). Heat Stress and Heat Disorder. Cassell, London.

- and Pallister, M. A. (1960). Lancet, 2, 114.

Moore, F. D., and Ball, M. R. (1952). The Metabolic Response to Surgery. Thomas Springfield Illinois.

Weiner, J. S., and Hellman, K. (1960). Biol. Rev., 35, 141.

Wilkinson, A. W. (1960). Body Fluids in Surgery, 2nd ed. Livingstone, Edinburgh and London.

\title{
Lactobacillus acidophilus (Enpac) in Treatment of Hepatic Encephalopathy
}

\author{
A. E. READ,* M.D., F.R.C.P. ; C. F. MCCARTHY,* M.D., M.R.C.P. ; K. W. HEATON,* M.B., M.R.c.P. \\ JOHN LAIDLAW, $\dagger$ M.B., M.R.C.P.ED.
}

Brit. med. F., 1966, 1, 1267-1269

The routine treatment of chronic hepatic encephalopathy is successfully accomplished in many patients by restriction of dietary protein and by the continuous use of oral non-absorbable antibiotics, such as neomycin (Dawson et al., 1957). This type of treatment, though often producing clinical improvement, has the following disadvantages: (a) neomycin is still relatively expensive (a week's treatment of $1 \mathrm{~g}$. three times a day costs $£ 66 \mathrm{~s}$.) ; (b) the treatment often becomes less effective as livercell function diminishes ; $(c)$ there is a small risk of toxic effects (particularly deafness) in patients who have impaired renal function (Last and Sherlock, 1960) ; and (d) resistant staphylococcal infections in patients or contacts may also occur (Alder, personal communication, 1965). Various other types of treatment have therefore been suggested and used, including that of " medical colectomy"-the colonization of the colon with nonammonia-producing bacteria. This type of therapy was reported by Macbeth et al. (1965) as being successful in the management of hepatic encephalopathy-the bacteria used for colonization being Lactobacillus acidophilus. In the two cases reported the patients were fed 1 or 2 litres daily of inoculated skimmed-milk medium containing $2.9 \times 10^{12}$ organisms/1. The protein content of this medium was $26-30 \mathrm{~g}$./1. This amount of protein may be toxic to the patient with hepatic encephalopathy (Phillips et al., 1952).

We have used a freeze-dried preparation of $L$. acidophilus (Enpac) in an attempt to assess the value of this treatment in moderate dosage in hepatic encephalopathy. We have compared the effect of Enpac with neomycin and tried to determine whether any benefit was to be gained from using combined (Enpac and neomycin) therapy in this disorder. The lactobacilli in this preparation are resistant to $7 \mu \mathrm{g}$. of neomycin per ml.

\section{Methods}

Enpac was administered in a dose of $20-40 \mathrm{~g}$. in four doses daily mixed with cold water. Enpac contains $1 \times 10^{7}$ organisms $/ \mathrm{g}$. Three patients also received $90 \mathrm{~g}$. in nine daily doses. Treatment was continued for one to four weeks.

\footnotetext{
- Department of Medicine, University of Bristol, at the Bristol Royal

t M.R.C. E.E.G. Unit, the Royal Infirmary, Edinburgh.
}

Patients also received lactose, 60 g. four times daily. Enpac on analysis has a protein content of $31.17 \%$ and also contains lactose $39.25 \%$ and dextrose $16.5 \%$. The dietary protein intake of all patients observed in hospital was maintained at $40 \mathrm{~g}$./day, and in one patient at $20 \mathrm{~g} . /$ day. Patients followed outside hospital were on a daily intake of $40 \mathrm{~g}$. protein. Control subjects took a normal diet.

Assessment of the effects of treatment was made by E.E.G. recordings, blood ammonia estimation, and bacterial examination of faeces.

E.E.G. Recordings.-Use was made of the technique described by Laidlaw (1959) and Laidlaw and Read (1963) in which E.E.G. rhythms are fed through an electronic wave-form analyser. Frequency distribution graphs of analysed rhythmic activity allow the calculation of mean frequency, slowing of which occurs in hepatic encephalopathy. Normal mean frequency is 8 or more c./s. In hepatic encephalopathy it slows, and in hepatic precoma it is $4 \mathrm{c}$./s. or less. Each patient had several E.E.G. records, the mean frequency on each occasion being obtained from analysis of five or more 15-sec. periods. Care was taken to make sure that basal E.E.G.s did not vary significantly before treatment was started.

Blood Ammonia.-Arterial blood was drawn from the brachial artery of the fasting and resting patient, and ammonia estimated by a modification of the method of Seligson (Seligson and Seligson, 1951) (normal arterial ammonia up to $100 \mu \mathrm{g} . /$ $100 \mathrm{ml}$.).

Bacterial Examination of Faeces.-Freshly passed specimens of stool were collected daily and cultured aerobically and anaerobically on blood agar, McConkey agar, and tomato agar. Colony counts of lactobacilli and coliforms were made by dilution of a known weight of faeces in broth and subsequent plate culture. Bacterial urease activity of total faeces and of coliform organisms was detected by culture in urea broth containing phenolphthalein. The following criteria were used for assessing L. acidophilus concentration in faeces:

Very scanty: 50,000 colonies per g. faeces

Scanty: 50,000-200,000 colonies per g. faeces

Moderate: 200,000-1,000,000 colonies per g. faeces

Profuse : $>1,000,000$ colonies per $g$. faeces. 